\title{
Thyroid Peroxidase Antibody among Hypothyroid Patients and Clinical and Biochemical Response to L-Thyroxine Replacement Therapy
}

\author{
Asish Kumar Debnath, ${ }^{1}$ Md Azizul Haque, ${ }^{2}$ Partho Moni Bhattachyaria, ${ }^{3}$ \\ Quazi Tarikul Islam, ${ }^{4}$ A R M Saifuddin Ekram ${ }^{5}$
}

\begin{abstract}
This study was carried out in the Department of Medicine, Rajshahi Medical College, in 20062007 to study the thyroid peroxidase (TPO) antibody level among hypothyroid patients and to find out the effects of L-thyroxine therapy in TPO-antibody titer. After thorough physical examination and relevant investigations, 100 patients of hypothyroidism were enrolled in this study. The selected patients were given L-thyroxine replacement therapy at a dose of 50-150 microgram/d. Before starting L-thyroxine, serum was collected from all patients to estimate anti TPO-antibody level. All patients were followed-up after 12-28 weeks of full dose of L-thyroxine therapy.

Patients with high TPO-Abs at baseline, only $17.6 \%$ turned into euthyroid (based on composite clinical score), whereas about $42 \%$ of the patients who did not have high TPO-Abs became euthyroid suggesting that patients with high TPO Abs may show significantly poor response to treatment compared to the patients without high TPO Abs $(p<0.001)$. Patients with high TPO-Ab titers also showed a decreased biochemical response (TSH values) compared to the patients without high TPO-Ab positive patients. So, TPO-Ab plays a significant role in causation of the disease and is also associated with poor treatment response with L-thyroxine replacement therapy.
\end{abstract}

Key Words: Hypothyroid, L-Thyroxine

TAJ 2018; 31: No-2: 45-49

\section{Introduction}

Hypothyroidism is a common endocrine disorder resulting commonly from failure of the gland to produce adequate amounts of hormone. Primary gland failure accounts for $90 \%$ to $95 \%$ of all hypothyroid cases. Many of these patients show evidence of an autoimmune origin of thyroid failure, with > 95\% developing antithyroid peroxidase antibody and/or antithyroglobulin (anti-Tg) antibodies. The TSH level is usually very high $(>15.0 \mathrm{miu} / \mathrm{L})$ with depression of FT4 $(<1.0 \mathrm{ng} / \mathrm{dl}) .{ }^{1,2}$ The prevalence rate of hypothyroidism depends upon population studied. Prevalence of primary hypothyroidism is $1: 100$ but may increase to 5:100 if patients with sub-clinical hypothyroidism are included. ${ }^{3}$ In the Framingham study, the prevalence rate of hypothyroidism was up to $20 \% .{ }^{4,5}$ In all studies, it was shown that a progressive increase in prevalence of thyroid antibodies was revealed with age in women, as

\footnotetext{
${ }_{1}^{1}$ Senior Consultant (Medicine), 250-bed General Hospital, Meherpur

${ }^{2}$ Associate Professor, Department of Medicine, Rajshahi Medical College

${ }^{3}$ Resident Physician, Rajshahi Medical College Hospital

${ }_{4}^{4}$ Professor of Medicine, Popular Medical College, Dhaka

${ }^{5}$ Research Fellow, Monash University, Melbourne, Australia
} 
compared to in men. These trends were confirmed in the original Whickham survey but the frequency of positive tests was lower. ${ }^{7}$ Most patients with spontaneous hypothyroidism have underlying chronic lymphocytic (autoimmune) thyroiditis and positive results on thyroid-antibody testing. In a review of three longitudinal studies (with 6, 10 and 20 years follow-up) of 2956 subjects, mild thyroid failure occurred at a rate of $2.1 \%$ to $3.8 \%$ per year in thyroid-antibody positive patients and in $0.3 \%$ per year in thyroid-antibody negative patients. ${ }^{9}$ The development of hypothyroidism also correlated with the strength of titre of antithyroid microsomal antibody at first survey. ${ }^{10}$

There is a definite relationship between Lthyroxine therapy and fall of thyroid microsomal and thyroglobulin antibodies in idiopathic myxoedema and in hypothyroid but not in euthyroid Hashimoto's thyroiditis. Chiovato Let $\mathrm{al}^{14}$ studied in this context. The changes in the serum thyroid auto-antibodies, anti-thyroglobulin (TgAb) and anti-thyroid-peroxidase (TPO-Ab), Lipid profile and thyroid volume following Lthyroxine therapy is still a controversial matter. Romaldini $\mathrm{JH}$ et $\mathrm{al}^{15}$ studied 23 patients with goiter due to Hashimoto's thyroiditis, 10 had clinical hypothyroidism (CH) and 13 had subclinical hypothyroidism (SH). Both groups received L-T4 (2.0-2.5 micro.gm $/ \mathrm{kg} / \mathrm{d})$ for a median of 6 months. Serum concentration of TgAb (normal value $<200 \mathrm{IU} / \mathrm{mL}$ ) and TPO-Ab (normal value $<150 \mathrm{IU} / \mathrm{mL}$ ) were measured by a sensitive IRMA using 1251 protein-A. At the end of observation period the median serum TSH concentration decreased significantly in both groups (42.9 to 0.55 in $\mathrm{CH}$ and 2.4 to $0.74 \mathrm{mIU} / \mathrm{L}$ in SH patients) and serum FT4 levels increased only in the $\mathrm{CH}$ group (0.87 to 2.1, $\mathrm{P}<0.05$ ). TPO$\mathrm{Ab}$ levels fall in the $\mathrm{CH}$ groups (871 to 194 $\mathrm{IU} / \mathrm{mL}, \mathrm{P}<0.05$ ) and no significant change was noted in SH patients (260 to $116 \mathrm{IU} / \mathrm{mL}$ ).

\section{Materials and Methods}

The study was carried out in the Department of Medicine, Rajshahi Medical College Hospital $(\mathrm{RMCH})$ and in the Nuclear Medicine Centre (NMC), Rajshahi during the period of January2006 to December 2007. The patients
(Hypothyroid) were selected from indoor, outdoor of RMCH and Nuclear Medicine Center of Rajshahi. Investigations were done in the Department of Biochemistry \& Department of Pathology of Rajshahi Medical College, NMC, Rajshahi and Department of Biochemistry BSMMU, Dhaka.

It was a Hospital based prospective study for estimation of thyroid peroxidase antibody among the hypothyroid patients and to find out the clinical and biochemical response of L-thyroxine therapy in the hypothyroid patients with positive thyroid peroxidase antibody. The clinical course of the disease was explained with each patient in details and they were enrolled after obtaining informed written consent, permission of the study and ethical clearance was taken from the concerned department prior to the study.

\section{Results}

In this study, 100 hypothyroid patients (diagnosed by clinical and biochemical findings) were taken to observe the demographic profile as well as the prevalence of TPO-Abs among hypothyroid patients before L-thyroxine replacement therapy. Mean ages of the hypothyroid patients were $23.7 \pm$ 4.9 years, which revealed that young adults were most commonly affected than elderly people and a female preponderance (74\%) was also observed. Nearly $90 \%$ of the patients complained of tiredness followed by weight gain (83\%), dry skin (71\%), leg swelling (70\%), hoarseness of voice (66\%), constipation (57\%) and cold intolerance (53\%). Goitorous hypothyroid patients were (28\%). Anaemia was present in majority of cases (81\%); periorbital edema (54\%) and cold periphery (30\%) were noted. Among all cases $84 \%$ of the patients were TPO-Ab positive and rest 16\% was TPO-Ab negative. Patients who had TSH value $>10 \mathrm{miu} / \mathrm{L}, 88.24 \%$ of them were TPO-Ab positive and those who had TSH value in between 6 to $10,66.67 \%$ of them were TPO-Ab positive. Among 74 female hypothyroid patients, 62 (83.78\%) were TPO-Ab positive, whereas out of 26 male hypothyroid patients, 22 (84.26\%) were TPO-Ab positive. 
Outcome of treatment of hypothyroidism with Lthyroxine in patients with high level of serum thyroid peroxidase antibodies (TPO Abs $>1000$ $\mathrm{IU} / \mathrm{ml}$ ) and in those without high level of serum TPO Abs $(\leq 1000 \mathrm{IU} / \mathrm{ml})$ were assessed. The outcome was evaluated in terms of clinical and biochemical responses to treatment. Among a number of clinical signs and symptoms, 12 signs and symptoms (based on weighted manner) were considered of value to find a composite clinical score. A score of ' 1 ' was assigned for the presence and ' 0 ' for the absence of each of those symptoms and signs (described in Material \& Methods) so that a total score ranging from $0-12$ could be attained by a patient depending upon the number symptoms and signs the patients had. To this score ' 1 ' point was added for female patients younger than 55 years old. The composite score thus obtained was divided into three categories hypothyroid (score 6 or more), intermediate (score 3-5) and euthyroid (score 2 or less). The biochemical response was evaluated after a minimum treatment of 12 weeks (median treatment was 16 weeks) whether the levels of serum $\mathrm{TSH}$ and $\mathrm{T}_{4}$ returned to normal range. The level of TSH was again subdivided into three categories- Overt hypothyroidism (TSH > 10 $\mathrm{nmol} / \mathrm{L}$ ), subclinical hypothyroid (TSH $6.01-10$ $\mathrm{nmol} / \mathrm{L}$ ) and normal or euthyroid (TSH 6 or less than $6 \mathrm{nmol} / \mathrm{L}$ ). The clinical and biochemical responses was first assessed relative to composite clinical score and serum TSH and $\mathrm{T}_{4}$ at baseline and then the outcome was compared between patients with high serum TPO Abs $(>1000 \mathrm{IU} / \mathrm{ml})$ and patients without high serum TPO Abs $(\leq 1000 \mathrm{IU} / \mathrm{ml})$ to determine whether high serum TPO Abs played any role in modifying the clinical and biochemical responses to treatment. The findings of the study obtained from data analyses are chronologically presented below.

High TPO Abs and clinical response:

Table I presents the association between high TPO Abs and clinical response. Of the 17 patients with high TPO Abs at baseline, only 17.6\% turned into euthyroid (based on composite clinical score), whereas about $42 \%$ of the patients who did not have high TPO Abs became euthyroid suggesting that patients with high TPO Abs may show significantly poor response to treatment compared to the patients without high TPO Abs $(\mathrm{p}<0.001)$.

\section{Table I: Distribution of patients by examination findings $(n=60)$}

\begin{tabular}{|c|c|c|c|}
\hline \multirow[b]{2}{*}{$\begin{array}{l}\text { Status }{ }^{\#} \text { of the patients at follow } \\
\text { up }\end{array}$} & \multicolumn{2}{|c|}{ TPO Abs (IU/ml) } & \multirow[b]{2}{*}{ p-value } \\
\hline & $\begin{array}{l}\operatorname{High}(>1000 / \mathrm{ml}) \\
\qquad(\mathrm{n}=17)\end{array}$ & $\begin{array}{l}\text { Not high }(\leq 1000 / \mathrm{ml}) \\
\qquad(\mathrm{n}=43)\end{array}$ & \\
\hline Euthyroid & $3(17.6)$ & 18(41.9) & \\
\hline & & & $<0.001$ \\
\hline Intermediate & 14(82.4) & 25(58.1) & \\
\hline
\end{tabular}

\# Data were analyzed using Chi-square $\left(\chi^{2}\right)$ Test and were presented as frequency (\%).

\section{High TPO Abs and biochemical response:}

Table IX demonstrates the association between high TPO Abs and biochemical response. Over threequarter (76.5\%) of the patients with high TPO Abs exhibited serum TSH level 6 or below $6 \mathrm{nmol} / \mathrm{L}$, $17.6 \%$ had overt and only 1 (5.9\%) case had subclinical hypothyroidism. Majority (81.4\%) of the patients with TPO Abs 1000 or less than $1000 \mathrm{nmol} / \mathrm{L}$ also had serum TSH 6 or below $6 \mathrm{nmol} / \mathrm{L}, 16.3 \%$ had overt 
and $1(2.3 \%)$ case had subclinical hypothyroidism. Serum TPO Abs level was not observed as the determinant of biochemical response $(p=0.774)$.

\section{Table II: High TPO Abs and biochemical response $(n=60)$}

\begin{tabular}{lccc}
$\begin{array}{l}\text { Serum TSH level } \\
(\mathrm{nmol} / \mathrm{L})\end{array}$ & \multicolumn{2}{c}{ TPO Abs (IU/ml) } & p-value \\
& $\begin{array}{c}\text { High }(>1000 / \mathrm{ml}) \\
(\mathrm{n}=17)\end{array}$ & $\begin{array}{c}\text { Not high }(\leq 1000 / \mathrm{ml}) \\
(\mathrm{n}=43)\end{array}$ & \\
$\leq 6$ (Normal) & $13(76.5)$ & $35(81.4)$ & \\
$6.01-10$ (Subclinical) & $1(5.9)$ & $1(2.3)$ & 0.774 \\
$>10$ (Overt) & $3(17.6)$ & $7(16.3)$ &
\end{tabular}

\# Data were analyzed using Chi-square $\left(\chi^{2}\right)$ Test and were presented as frequency (\%).

\section{Discussion}

Iodine deficiency remains the most common cause of hypothyroidism world-wide. In areas of iodine sufficiency, autoimmune diseases (both atrophic and goitorous form of Hashimoto's thyroiditis) and iatrogenic causes (treatment of hyperthyroidism) are the most common causes of hypothyroidism. Among 100 hypothyroid patients where $84 \%$ patients were TPO-Ab positive may indicate a higher proportion of patients are suffering from autoimmune thyroid disorder. Those who are in high titers $(>1000 \mathrm{IU} / \mathrm{mL})$ showed significantly poor response to treatment compared to the patients without high titers of TPO-Abs $(p<0.001)$. So what precedes these events awaits further study. The present study had several limitations. The follow-up duration of study period was short. A significant proportion of patients lived in remote area and was very much reluctant to come at follow-up. Anti-TPO-Ab test was not available at Rajshahi and for that reason Investigator himself visited BSMMU, Dhaka with sample several times. It was time and cost consuming. TPO-Ab test was expensive. Following interferences may be drawn from the present study:

1. A significant proportion of hypothyroid patients in anti-TPO-Ab positive.
2. There is a decreased clinical and biochemical response to L-thyroxine replacement therapy among high titre TPO-Ab positive hypothyroid patients.

\section{Conclusion}

It is assumed that TPO-Ab plays a significant role in response to treatment with L-thyroxine replacement therapy. So, to get significant results of treatment with L-thyroxine to high titre TPO$\mathrm{Ab}$ positive hypothyroid patients needs or awaits further study.

\section{References}

1. Orlander PR, eMedicine- Hypothyroidism. http:// www.emedicine.com/MED/topic 1145.htm

2. Dillman WH. The Thyroid. In Gill GN. Endocrine diseases. Cecil Text book of Medicine. $21^{\text {st }}$ ed. Philadelphia, WB Saunders; 2000:1179-1317.

3. Walker BR, Toft AD, Endocrine diseases, Haslett $C$, Chilvers ER, Boon NA, Colledge NR, Hunter JAA [eds], Davidsons Principles and Practice of Medicine,19th edn, 2004; 16: 691.

4. Dauntus LH. Review-' Thyroid disease and lipids' Thyroid 2002; 12: 287-93.

5. Swain CT, Castelli WP, Hershman JM, Mc Namara P, Bacharach P.' The aging thyroid' Thyroid deficiency in the Framingham study' Arch Intern Med 1985; 145: 1386-88.

6. Alam MN, Haq SA, Ansari MAJ, Karim MA, Das KK, Boral PK, et al. Spectrum of thyroid disorders in 
IPGMR, Dhaka, Bangladesh J, Medicine 1995; 6:53-58.

7. Tunbridge WMC, Evered Dc, Hall R, Appleton D, Brewis M Clark F, et al. The Spectrum of thyroid diseases in the community. The Whickham survey. Clin Endocrinol 1997; 7: 483-93.

8. Stall b JJ, Althaus BU, Engler $\mathrm{H}$, et al. Spectrum of subclinical and overt hypothyroidism: Effect on thyrotropin, prolactin and thyroid reserve and metabolic impact on peripheral target tissues, Am J, Med 1992; 92: 631-42.

9. Toft AD. Thyroxine therapy, Review Article. N Engl J Med 1994; 331: 147-80.

10. Tunbridge WMG, Brewis M, French JM, Appleton $D$, Bird T, Clark $F$ et al. Natural history of autoimmune thyroiditis. BMJ 1981; 282: 258-62

11. Czamoeka B, Ruf J, Ferraud M, Carayan P, Lissitzky S. Purification of the human thyroid peroxidase and its identification as the microsomal antigen involved in autoimmune thyroid diseases. FEBS lett 1985; 190: 147-52

12. Doullay F, Ruf J, Carayon P, Codaccioni J L. Autoantibodies to thyroperoxidase in various thyroid and autoimmune diseases. In: Carayon P, Ruff $\mathrm{J}$ [eds]. Thyroperoxidase and Thyroid Autoimmunity. Colloque INSERM, Vol 207, John Libbey, London, PP. 285-95 (1990).

13. Chiovato L,Marcocci C, Marrioti S, Mori A, Pinchera A. L Endocrinol Invest (1986) Aug; 9 (4): 299-305

14. Romaldini JH, Biancalana MM, Figurivedo DI, Farah CS, Mathias PC-Thyroid, 1996 Jun; 6 (3): 183-8

15. Barker DJ, Bishop JM, Computer-based screening system for patients at risk of hypothyroidism. Lancet. 1969; 2 (7625): 835-8

16. US preventative services Task Force- Screening for thyroid disease: recommendation, statement. Ann Inern Med. 2004; 140 (2): 125-7

17. Chu JW, Crapo LM, The treatment of subclinical hypothyroidism is seldom necessary $\mathrm{J}$ Clin Endocrinol Metab2001; 86: 4591-99.
18. Mc Dermott MT, Ridg Way EC, subclinical hypothyroidism is mild thyroid failure and should be treated, J Clin Endocrinol metab 2001; 86: 4585-90.

19. Adlin V. Subclinical hypothyroidism: Deciding when to treat. Amer Fam Physician. 1998; 57 (4): 776-80.

20. Harris B, Fung $H$, Johns $S$ et al (1989). Transient Post partum thyroid dysfunction and post natal depression. Journal of affective disorders,17; 24349

21. Pop V J,de Rooy, H J Vader, H L.,et al. Post partum thyroid dysfunction and depression [letter]. New England Journal of Medicine 1991; 324: 181516.

22. Pop V J, de Rooy, H J Vader, H L et al, Microsomal antibodies during gestation in relation to post partum thyroid dysfunction and depression. Acta Endocrinologica, 1993; 129: 26-30

23. Randomised trial of thyroxine to prevent post natal depression in thyroid-antibody positive women. The British Journal of Psychiatry(2002) 180: 327-30

24. Wiersinga WH. The thyroid and its diseases; Adult hypothyroidism, March 4, 2004

25. Van Vilet G. Treatment of congenital hypothyroidism. Lancet 2001; 358: 86-87.

26. Geul KW, Van Sluisveld ILL, Grobbee DE, Doctor $\mathrm{R}$, de Bruyn AM, Hooykaas $\mathrm{H}$ et al. The importance of thyroid microsomal antibodies in the development of elevated lipids. Clin Endocrinol 1993; 39: 275-80.

27. Vanderpump MPJ,Tunbridge WMC, Epidemiology and prevention of clinical and subclinical hypothyroidism. Thyroid 2002; 12:839-47

28. Parle JV, Franklyn JA,cross KW, Jones SC and sheppared MC. Prevalence and follow-up of abnormal thyrotropine concentrations in the elderly in the united Kingdom. Clin Endocrinol 1991; 34: 77-83.

29. Jameson JL, Weetman AP. Disorders of the thyroid gland. In Braunwald E, Fauci AS, Kasper DL, Hauser SL, Longo DL, Jameson JL [eds]. Harrisons Principles of Internal Medicine. $16^{\text {th }}$ edn.Vol-2, Mc Graw Hill. Inc. 2005: 2104-2106 